\title{
Sectarianism in Sunnī Islam
}

\author{
Ronald Geaves
}

\section{1 \\ Introduction}

Any attempt to understand sectarianism within the Sunnī tradition of Islam will require acknowledging the perceptions of those among the majority of Muslims that have formed Islamic political and religious reality over the centuries into the present time, recognising the tensions between the real and the ideal, and the overriding conflict between the actual (schismatic division) and the perception (an undivided umma). Some may feel that the term 'sectarian' does not accurately reflect the reality of Sunnī Islamic divisions. ${ }^{1}$ Yet an alternative term, such as the Arabic madhhab, poses similar problems as it is generally used to describe the four orthodox schools of law or jurisprudence ( fiqh) in Sunnī Islam. The four Sunnī schools are Hanafì, Hanbalī, Shāfì̄ì and Mālikī. They are joined by two Shī‘a schools, Ja'farī and Zaydī. These schools are predominantly regional and rule over questions of religious law and as such they cannot be described as 'sects'. The same reasoning applies to the early historical theological schools $(\mathrm{kalām})$. They were more a scholarly exercise in theological questions, undertaken to correct or reassure those that doubted. Majid Fakhry defines kalām as an attempt to grapple with complex issues arising out of the Qurān's understanding of God and creation; for example, free will, predestination, the eternal as opposed to the temporal reality of the Qur'ān as Word of God (Fakhry 1983: xvii-xviii). It is true that although Ilm al-Kalām is not so much a sectarian activity, various divisions within both Sunnī and Shī‘a Islam may favour one interpretation over another. ${ }^{2}$ Most difficult perhaps is the notion that 'sectarianness' problematises the ideal of an undivided umma which remains a key element in the Islamic imagined community (Anderson 1991). A vision of non-sectarianism has often been used as a

1 I was advised as such in 1990, when I began my doctoral thesis Sectarian Influences within Islam in Britain (Geaves 1996).

2 Since Sunnīs often define(d) themselves in opposition to the Shīa and emerged as a competing theological and political grouping against the Shīa, arguably one cannot discuss sectarianism within Sunnī Islam without consideration of the role of the Shī'a. However, this volume locates Sunnī movements and Shīa movements in different parts of the text, and I have therefore omitted discussion of Shī'a sectarianism in this chapter. 
critique of Christianity, especially in Muslim apologetics and found frequently amongst converts (Geaves 2010: 48-53; Gilham 2014: 130,154).

The issue is one of definition. Classical sociological theory defines a 'sect' as having various characteristics, mainly derived from early sociologists' attempts to grapple with divisions in Christianity. It is precisely this awareness of the multitude of various sects or denominations within Christianity that may make Sunnī Muslims wary of the term; yet an analysis of sociological definitions does not, in my view, render such understandings of sectarianism unfruitful in the context of the variety of Islamic movements that exist, sometimes uncomfortably, alongside each other in the Sunnī Muslim milieu. Nonetheless, critical engagement with the traditional academic usage of 'sect' is a needed endeavour should we continue to use the term to discuss Islamic movements in the twenty-first century.

Early sociological attempts to analyse and define 'sects' began with Max Weber (1864-1920) who posited that people are born into a church but elect to join a sect (Weber 1973: 140-149). These ideas were developed by Ernst Troeltsch (1865-1923) in 1912 (Troeltsch 1931). In essence both sociologists work with a sect/church dichotomy in which sects branch away from a parent religion as a protest movement against perceived watering down or liberalisation of the initial charismatic moment that began a new 'world religion'. In turn, founders of sects will usually demand a return to the 'true' or 'authentic' religion as they perceive it, whereas the parent religion will usually accuse the sect of aberration, apostasy or heresy. Thus Fred Kniss and Paul Numrich can state that sects are best described with regard to what they oppose or are in tension with (Kniss and Numrich 2007). Rodney Stark and William Sims Bainbridge agree with the Weberian approach and add that "sects claim to be authentic, purged, refurbished version of the faith from which they split" and often this expresses itself with a high level of opposition or resistance to the surrounding society (Stark and Bainbridge 1979: 117). Roy Wallis attributes to sects "epistemological authoritarianism," meaning that sects justify their particular "heresy' by claiming to "possess unique and privileged access to the truth" or salvation, and adds that committed sectarians typically believe "that only error exists outside confines of the collectivity" (Wallis 1975: 93). The awareness of elite access to truth, and the corruption inherent in the wider society or weakening of the parent faith, usually means that a sect is marked by a degree of boundary maintenance tactics (McGuire 2002: 338). 
There are difficulties in applying the above Weberian-influenced analyses in Islam, but there are Muslim correspondences that can help identify Sunnī sectarianism. As already stated, the ideal of the umma as a singular, divinely revealed, and united Islamic community, tends to dominate in Sunnī Islam, with variations among different groups as to who should be included. Talal Asad draws upon a notion of a "discursive tradition" in which knowledge is historically and culturally constituted in the interactive space between people, texts and practice to describe such divisions (Asad 1986). The Sunnī ideal is encapsulated in the phrase Ahl al-Sunna wa-l-Jamāat (the party of the sunna), yet there have been, and continue to be, diverse interpretations of Sunnī Islam and each group is likely to lay claim to being the most 'authentic'. The Muslim community was already torn by dissent and split into factions within the lifetime of the first generation of believers, and even the Qur'ann acknowledges the existence of sects ( $t a \bar{t} i f a)$, signifying a smaller group that has broken away from a larger whole but which has also developed a discrete and coherent religious worldview of its own. As stated by Fuad Khuri, țäifa indicates a "split-off group possessing a religiously autonomous character" (Khuri 1990: 28). Khuri also cites terms like firqa (team) and nihla (religious order) as specific instances of such groups in Islamic discourse (Khuri 1990: 27-28). Firqa can be understood to mean a number of sub-divisions or groups within one țäifa; for example, the various movements within Shī'a. However, nihla or firqa provide a different understanding of sectarianism that is more pertinent to divisions within the Sunnì mainstream. For example, Khuri notes that the twelfth century Persian scholar Muhammad al-Shahrastānī uses nihla in opposition to milla (a nation ruled over by a body of religious law). Thus, the nation of Israel, for example, is ruled over by one law revealed by God but may contain many religions or even different interpretations of the law within it (Khuri 1990: 28). These terminologies have the benefit of utilising existing Arabic or Muslim understandings of schism and will help to provide an analytical framework for the causes of schism within Sunnī Islam.

\section{3} Sect and Community

Underlying this analysis of Sunnì sectarian is an awareness of what Sunnī scholars and activists have considered to be authenticity and remaining true to the primal message, or, on the other hand, what they considered to be deviation (bid'a) from an imagined 'pristine' message. If Shahrastānī's use of milla corresponds in a Muslim framework to umma, an imagined unity of all believers, guided by the word of God and the actions of the Prophet Muhammad, 
and believed to possess a moral mission to create a new social order based on faith and obedience to the revelation, firqa or nihla can be utilised to correspond to various movements and divisions within the umma, without recourse to the classic Western sociological understanding of sect. The umma is held together not by any formal organisation but by a collective act of will, inspired by personal conviction and embodied in the ritual duty of daily prayer, the month long fast of Ramadan and the annual pilgrimage to Mecca (Moten 1996: 63-81). Five times a day, millions of Muslims face Mecca all at the same time to observe the same ritual prayers. This core of shared ritual practices combined with observances of sharîa is integral to Muslim life and creates the bonds that tie the umma together (Geaves 1996: 11).

These rifts are acknowledged in Islam's sacred literature, for example, in the hadīth narrative credited to Muhammad by Abū Hurayra: "The Prophet (peace be upon him) said: 'The Jews were split up into seventy-one or seventy-two sects; and the Christians were split up into seventy-one or seventy-two sects; and my community will be split up into seventy-three sects."3 Another version of the same theme is where the Prophet says of the sects: "Only one will be saved. The others will perish.' When asked which was the one that would attain salvation, he replied: 'Those who follow al-Sunnah wa-l-jama'ah.' He was further asked: 'What is al-Sunnah wa-l-jama'ah?' He replied: 'That which I and my companions practice."' It is important to note that hadith are not historical documents and like the Qurān are employed in ahistorical and ideal-typical fashion when discussed in relation to political and social issues.

The Qurān can also be drawn on as a source in support of the saved elect. Islam as a fully formed umma is a moral community which not only hears the Law but upholds and enforces it (Qurān 3:110). A Godly umma is obedient and faithful, and according to the Qur'ān it is bound to be successful (Qurān 3:179). The righteous umma is the saved umma. As far back as the early Meccan period, however, the Qurān warns that even within the umma of believers there will be varying reactions to the message. There will be those who will fall away, and there will be those who are half-hearted (Qur'ān 35:32). One verse of the Qur'ān highlights this problem, and appears to offer the solution to it, when it uses umma in a specialised sense. Although usually the term umma applies to the totality of Muslims, it is also used to mean a righteous group of believers

3 S. Dawud (ND) Model Behaviour of the Prophet (Kitab al-Sunnah). At https://sunnah.com/ abudawud/42 accessed 27 October 2018.

4 Ssekamanya Siraje AbdAllāh, "Ibn Taymiyyah on the Ḥadīth of the 73 Sects." Jurnal Akidah \& Pemikiran Islam 7:1 (2006), 35-62. 
who have been selected from the wider community and who are charged with the duty of inviting other Muslims to obedience. The Qurān states "And let there be [arising] from you a nation inviting to [all that is] good, enjoining what is right and forbidding what is wrong, and those will be the successful" (3:104). This righteous and faithful umma within the wider umma functions as a guide and arbiter. This particular passage could be used as a justification for sectarianism in Islam. A self-defined righteous group within the wider community could draw upon this verse to make the claim that they were the true umma and in recent times they have increasingly done so.

Clearly in any division within the Sunnī ranks is going to consider itself to be the 'saved sect' and all other groupings to be the seventy-two who perish. This hadith has grown in prominence in the twentieth century, and the borders between the groups have become more distinct and aggressive as both claims of political leadership and religious legitimacy, have moved into one province of representation, the right to claim authentic or 'pure' Islam, a claim based on the belief that the Islam practised is sunna, the way followed by Muhammad and his companions. Ahl al-Sunna, 'people of tradition', referring to Sunnī Muslims, is thus highly contested. A number of movements and strands of Islam use the title to define themselves, not in the neutral sense of Sunnì identity, but in a highly charged atmosphere of claiming legitimacy, authenticity and a sense of specialness. The appropriation of the title as a religious identity label also serves to fix rival movements as 'other': at best deviant or guilty of innovation, at worst, to be branded by the tool of fatwa as non-Muslim or even as idolators (Geaves 2009).

\section{$4 \quad$ Routinisation}

Major stress was placed on the umma by the spread of the Arab empire and its attendant rapid incorporation of older, more sophisticated cultures brought into the fold of Islam and the imperative to establish good and efficient governance based upon God's ordinances (Esposito 1988: 46). Any attempt to formulate an overriding theory of Sunnī schisms in Islam would need to take account of these factors and also acknowledge both religious and political tensions. Sunnīs have tended to disagree on matters of interpretation of law or to changes in a group's doctrines and/or degree of strictness arising out of such processes of legal/religious interpretation but most deeply felt differences tend to occur historically within the context of debates on governance, especially the 'true nature' of the caliphate (Geaves 20og: 39). It is with these 
divisions that this article is primarily concerned yet caution needs to be taken in these analyses as splits can also be driven by ethnic, tribal, racial, or national fault lines.

The rise of the Arab empire after the death of Muhammad can be seen as a classic example of 'mixed motivation'. Although Weber's classic church-sect thesis is not very helpful in understanding divisions within Islam, his ideas on routinisation as developed by Thomas O'Dea are more fruitful. O'Dea posited five dilemmas that face new religions after the death of a founder: namely the dilemma of mixed motivation; the symbolic dilemma; the dilemma of administrative order; the dilemma of delimitation; and the dilemma of power (O'Dea 1964: 7iff). The first dilemma identified is particularly useful for the arguments presented here. In the dilemma of mixed motivation, O'Dea argued that the only motivation of the founder-innovator is communicating his or her message, but that successors will have additional motivations, such as personal power, prestige, status, and influence (Foy 1978: 300-301).

O'Dea's notions of schism permit an historical analysis beginning with the origins of Islam, through to the foundation of the Umayyad Empire, and even have repercussions in the present day. The dominant group among the inhabitants of Mecca, were the Banū Umayya, a wealthy clan of the Quraysh tribe. Amongst the Meccan merchants, it had been the Quraysh who had most to lose from Muhammad's preaching on social justice. In addition, they feared the loss of income associated with the tribal pilgrimages into Mecca to worship the gods and goddesses installed in the ancient Ka'ba (Lapidus 1988: 25). Many of the most aggressive opponents of the new religion and its leader were members of the Quraysh and had fought against the Muslims in the battles that took place before Muhammad's victorious entry into Mecca. Muhammad's final victory brought many of his enemies into the fold of Islam where they quickly established their position amongst the elite of Arab society (Lapidus 1988: 55).

By the time of the third caliph, 'Uthmān ibn 'Affān (576-656 CE) elected in $644 \mathrm{CE}$, the Arabs had expanded their territory to include much of Persia, Byzantine Syria, Egypt, North Africa, and Jerusalem. 'Uthmān belonged to the Banū Umayya and favoured his relatives and supporters, appointing them to positions of authority throughout the expanding empire (Lapidus 1988: 56 ). In Damascus, Mu'āwiya ibn Abī Sufyān (d. 680) became the most powerful of the Umayyad rulers, governing over Syria. Ironically much of the Muslim world was now ruled over by representatives of the old ruling Meccan clans that had for years opposed Muhammad and his message (Geaves 2009: 40). After 'Uthmān's assassination in $656 \mathrm{CE}$, Muhammad's cousin and son-inlaw, 'Alī ibn Abì Ṭālib (6oo-661 CE) of the Banū Hāshim (the only one of the first four caliphs recognised as legitimate by Shīa Muslims), succeeded to 
the caliphate. ${ }^{5}$ However, this was disputed by the supporters of the Umayya clan who departed from Medina and took up residence in their power base of Damascus (Geaves 2009: 41). After 'Alī's death at the hands of an assassin in $661 \mathrm{CE}, \mathrm{Mu}$ âwiya took control of the caliphate, turning it into the first dynastic Muslim empire, the Umayyad era (Lapidus 1988: 56).

The succession of Muāwiya was to have two repercussions. First, no longer could the caliphate be considered a religious institution, a fact recognised by many later Sunnī Muslims who would come to declare only the first four caliphs to be divinely guided. The apparent loss of the Prophet's and his companions' asceticism and religiosity amongst the new rulers led to many of the devout separating themselves from the activities of the court and living in semi-retreat in Medina where they attempted to recreate the lifestyles of the first Muslims. To this development can be traced the first roots of Șüfism or Islamic mysticism. But in addition, these issues of authority would dictate that politics and religious leadership were to play a role from the very beginning. Although the first armed struggles between Muslims to take place shortly after the death of Muhammad were the so-called ridda wars (Wars of Apostasy) during the first caliphate of Abu Bakr (574-634 CE), it is difficult to ascertain whether these conflicts with Arab tribes were caused by a rejection of Islam or a rejection of the office of the caliphate, although they were later seen as religious (Afsaruddin 2015: 62-63). However, another factor may have been the issue of nominal allegiance to Islam that arose through accepting the temporal power of Muhammad as a protector, a common practice among the tribes of Arabia.

A number of elements can contrive to form separatist or rebellious movements against the unity of state and religion within Sunnī Islam. The degree to which Islam is actually practised by Muslims can be controversial and even a cause of political rebellion. The question of whether nominal Muslims were within the fold of Islam arose early in Islam's development and is a continuation of the hypocrite (al-munäfiqün) concerns that arose in Medina. The first movements to declare war against the Umayyad state were the Kharrijites, who were unequivocal that the defining feature of Muslim identity was piety, and who controversially claimed the right to declare jihād against nominal Muslims, stating they were kufr or unbelievers. The state was quick to recognise that such a position led to unrest, civil wars and anarchy, and adopted the Ash'arite position that only God could judge the condition of imann (faith).

5 Fred M. Donner has argued recently that the early leaders of the nascent Muslim community did not refer to themselves as caliph at all, but as amir al-mu'minin (Commander or Leader of the Believers). See Donner (2010: 98-99). 
Nevertheless, the Khārijite position has never disappeared and has re-emerged dramatically in the twentieth century amongst various jihäd or takfiri (declaring other Muslims to be unbelievers) movements (Timani 2008).

The Khārijite rebellion against the Umayyad state reveals the tensions that arose over leadership, resulting from concerns over the parameters between religious and temporal leadership. As rulers the Umayyads were able to utilise the state as the main means of organising religious life. Indeed, Khuri goes as far to state that Sunnīs feel "lost" when deprived of centralised power (Khuri 1990: 99). The caliph or sultan has ideally embodied both governance and piety but ruling through the implementation and execution of sharita, the divine law. Ideally, he is not there to create laws, as these have already been given in entirety by Allāh. Any difficulties of interpretation are resolved by bodies of 'ulamä' or religious scholars, experts in jurisprudence. Although the dominant Sunnīs are more likely to speak of consensus and unity, even arguing that rebellion is not permitted against unjust rule, Khuri argues that sectarian divisions can be a means to reject the centralised authority of the Muslim state (Khuri 1990: 40-41). Such action is justifiable if the state rejects the correct application of Islamic principles with regard to the role of religion in politics.

Similar to the Khārijite position on individual allegiance to Islam, rather than nominal state or tribal loyalty, is the issue of state loyalty to the religion. In practice the union of revelation and governance has not always been watertight. Many rulers have been at odds with the 'ulam $\bar{a}$ ' with regard to authority and not all have implemented the shar'ia. Most of today's Muslim states have either discarded sharita law or mixed it in varying degrees with legal systems adapted from various European codes. It is only family law that has remained sacrosanct (Geaves 20o9: 50). The compromise with the political union of $\operatorname{din}$ (religion) and dunya (world) has led to some movements and organisations that condemn the state and seek to implement an Islamic revolution, sometimes through violent overthrow (Geaves 2009: 50), amongst such movements al-Qāiida, and Daesh (Islamic State or ISIS) can be categorised. As noted already, the justification for such movements in Sunnī Islam is to reform ('ișläh) or revitalise Islam and they interpret the legitimacy to do so, as did the Khārijites, on the Qurānic passage al-Imran 104. Originally revealed in Medina, probably as a reaction to the recruiting of various tribes whose religious motives were suspect, the political and religious significance of this verse can be highly subversive for Muslim states who are seen by the devout to have compromised God's revelation (Geaves 2009: 50). In the twentieth century, a number of revivalist movements have set themselves up as a righteous vanguard to renew Islam and purge the community of anything that is perceived to be a threat to the religion. Not all use violence, but such groups compete 
heavily with each other, as to which movement constitutes the righteous remnant apparently spoken of in the Qur'ān (Geaves 2009: 50).

As stated, arguably sectarianism began with the Umayyad dynasty. The succession of Mu'āwiya led to questions over the nature of his rule and the relationship between religion and politics, both clearly part of the legitimacy or, at least, the methodology of Islamic power. The Ummayads were a fait accompli, and under their leadership the Arabs became a new force in the world, extending an empire throughout Persian and Byzantine territory (Lapidus 1988: 58). Theologically, such expansion could be justified as evidence of the doctrine of "Manifest Success" (Qur'ān 48), which asserts that divine favour is evidenced by political success, expansion or prosperity, but by some the Ummayad rulers were seen to be usurpers, in violation of the Sunnī precedent, that began with Abū Bakr, that is, the community chooses its rulers according to the principles of Islam. Mu'āwiya was perceived by many of the devout to be a tyrant, a ruler who transformed the Islamic caliphate into a "kingdom" (Qur'ān 67). The event would lead to considerable argument concerning the role of the caliph and even the nature of prophethood, at least, as exemplified by Muhammad.

To some, the caliphate had to be governed by religious principles, in accordance with Qurān and sunna. To other scholars, a tyrant could be pragmatically accepted in order to maintain civil order and avoid bloodshed, but only as long as the people were permitted to practice Islam without hindrance. If the caliphate was a political office, such pragmatism was justified, and indeed became the normative mode of operation among Sunni Muslims, but if the caliphate was perceived to be the Prophet's deputyship, it then acquired religious authority, and disobedience to the caliph could be constituted to be disobedience to God (Lapidus 1988: 228-289). Mușțafā 'Abd al-Rāziq (1888-1966), an Egyptian scholar considered by some to be Islam's first secularist, would embody the former position, arguing that the caliphate is strictly political, concerned only with administration of empire. In Islam and the Foundations of Political Power (Al-Islam Wa Usul Al-Hukm) first published in 1925, he stated that new ways of governance were permitted, and that Islam has no role to play in political life (al-Raziq 1966 [1925]). Bakhìt al-Muțīi (d. 1935), the Grand Mufti of Egypt, took the opposite position.

In 1926, al-Muții i published his treatise in response, in which he argued that religious and political authority is embodied in Islam, a position that makes it unique from all other religions. The Prophet, he argued, combined in his person delivery of the divine message (al-risāla) and political office $(a l-h u k m)$. He argued that al-Rāziq was wrong to argue that Muhammad was only sent to establish religion and not a state. As the caliph acts as the deputy of the Prophet, his authority to govern is from God. In such thinking, one of 
the fundamental objectives of Islam is the foundation of a state so that the legal system of Islam can be implemented and to avoid the loss of Muslim dignity implicit in being ruled by non-Muslims or, even tyrannical Muslims (Afsaruddin 2015: 63-66). These differences over the political and religious functions of the caliphate were able to radically divide the Sunnì community, especially when Muslim power was threatened, the caliphate dissolved, or the territory lost, all of which would take place after the advent of European power in the contemporary period.

According to some assessments, for example, Reynold A. Nicholson (1989 [1914]), Șúfi origins lie in a non-political or quietist reaction to the worldliness of the Umayyad caliphate, an attempt to preserve the piety of the original community, through a retreat to Medina, and avoidance of Damascus and the new urban centres of the caliphate and its expanding empire. Any analysis of Șüfism as a sectarian movement within Sunnī Islam is complicated: first, by the academic study of mysticism, which distorts Șūism through a lens focused on mystical individuals, often antinomian in their relationship with orthodoxy (Dressler et al 2009: 4); and second, as its critics within Sunnī traditions perceive its origins to be outside Islam and who accuse it of bid'a (innovation) and shirk (placing others before God). Both the orientalist approach and the vociferous criticism from within certain modes of Sunnī understanding would tend to reinforce views of Șūfism as a sect within the greater whole (Dressler et al 2009: 1). However, this focus loses sight of the reality that Șūfism has historically been part and parcel of the normative interpretation of Sunnī understandings of Islam and remains so even today, especially outside of the Arab hinterlands. As such it deserves to be treated as a unique formation of ta $a$ if $a$ consisting of many firqa. It is also the main avenue through which charismatic leadership continues to be part of Sunnī tradition.

As mentioned above, Șūism, sometimes defined as Islamic mysticism, but more likely to be known as dhikr (remembrance of God) by its Sunnī practitioners probably began as a ascetic reaction to Umayyad worldliness (Lapidus 1988: 99). From these early examples of asceticism and withdrawal appeared a variety of movements composed of disciples to various spiritual guides who taught paths to self-purification based on the remembrance of Allāh's names (tașawwuf). As Șūfism formalised itself under the guidance of a number of skilled exponents of its disciplines, a variety of 'maps' appeared that are identified as 'stages' (maqāmāt) and 'states' (aḥwa l) on the progress within the 
path to self-annihilation in God. Each of these variations on a theme became distinct orders (țariqa) of Șüfism, each with a founding master (shaykh) and a lineage of masters that succeeded him (Haeri 1990: 19-20). Taríqa are considered by most Șūfis to complement the outer practices of Islam (sharīa). Discipleship is central to Șūfism, to provide guidance to the murìd (student) along the way of transformation from a self-centred existence to one which is God-centred (Geaves 2005: 124).

These mystical doctrines and practices developed into a cult of sainthood, in which a hierarchy of deceased saints who are believed to maintain the spiritual well-being of the world from outside time combined with popular belief and dependence upon living shaykhs, to create the doctrine of karämāt or special favour that was bestowed upon the saint to perform miracles and even intercede on behalf of those requiring Allāh's mercy and assistance (Geaves 2000: 17-18). This belief in miracles caught the imagination of the populace and led to extravagant and fantastic stories of the deeds of Șufis. When the shaykhs died the religious piety of their followers was directed to their graves which would then develop as important shrine centres and the focus of the continuing development of the tariqa. It was believed that the power to intercede and perform miracles was contained within the remains of the saint who was in some way still alive awaiting Judgement Day (van der Veer 1992). Similar to the Shi'a belief concerning their Imams, it was also believed that the Sunf's power was retained in his bloodline and it was usually his immediate remaining family who would take over the religious functions and administration of the shrine. The proliferation of shrines of deceased saints brought a new dynamic into Muslim belief and practices as millions of rural adherents concentrated their devotional practices and petitions around the tombs (Ernst 1997: 73-74). The rapid expansion of Șüfi teachings infiltrated the Islamic consciousness as the tariqa networks spread throughout the Muslim world in a spider-web pattern. Although the silsila (lineage) chains functioned to ensure the legitimacy of the individual shaykh and the teachings that he promoted, time and distance enabled many teachers to attract followers with less cred-

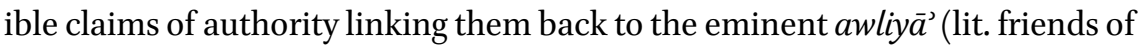
God) and eventually the Prophet.

The loosely organised localised structures of the tariqqas around an individual shaykh and his followers allowed for no central control of either doctrine or practices. Even reputable shaykhs had little control over belief and practice outside the inner circle of followers. The classic pattern of Șüfi allegiance which still exists to the present day, consisted of an inner circle of initiates who resided with the shaykh and an outer circle who still maintained the shaykh's teachings but also had other more worldly priorities. The shaykh could exercise 
a considerable degree of control over these two groups of followers. However, outside of these groups of loyal and committed disciples there was a wider circle that took bai'at (initiation) with the shaykh as a means of acquiring status and prestige in their social milieu. Over this group the shaykh would have little control, either over their behaviour or the way in which they promoted his teachings and spiritual prowess (Geaves 2000: $76-77$ ). The more they communicated stories of miraculous powers to the credulous, the more their own reputations soared through vicarious holiness or sanctity. Outside these three groups of followers would have been an even larger group of the general populace who would have used the shaykh to resolve a whole range of medical, social and psychological problems through access to his spiritual counsel or belief in his miraculous powers based on his proximity to Allāh. Finally, an even more nebulous connection to the shaykh existed in the wider population, based on pride or status in having such an elevated figure in their locality (Geaves 2000: 17-18).

The development of a fully-fledged theosophy of sainthood, both living and in the tomb, troubled many orthodox Muslims, especially amongst the ranks of the 'ulam $\bar{a}$. There was considerable criticism of the need to submit to the authority of charismatic men who claimed a special relationship to Allāh through ecstasy (van der Veer 1992). Some believed that Islam was being subverted through vicarious holiness arising out of dependence on saints, pilgrimage to their shrines, adoration of their relics and total commitment of physical and mental resources to their service (Nicholson 1989 [1914]: 146). Others argued that the emphasis on saints was foreign to Islam and offensive to teachings of Muhammad (Knysh 2017: 21).

The other major criticism of Șüfism appeared from both outside and within its own ranks. As observed above, some Süfis began to assert that the intimate relationship with Allāh which is enjoyed by the wali (friend of God) negates the requirement of obedience to the outer laws of Islam, that is sharita. Some suggested that obedience to the exoteric laws and requirements of Islam was a duty required only during the early stages of spiritual development. It was inevitable that a dichotomy should arise between the experience of those who claimed direct inner access to the divine and therefore felt themselves to be completely surrendered to the divine will and those who dutifully followed the external requirements of the sharita. Although Ibn Arabi would argue that there is no contradiction with conventional Islamic doctrine, as it would not be possible for the man of self-knowledge to contradict the revelation brought to the messenger of God, such a doctrine is open to abuse by charlatans and religious impostors claiming to be such elevated beings. Although, for most, 
the inner path complemented the outer, for others the experience of God's presence within supplied an authority that overrode the historical revelation.

If such sentiments are followed through to their ultimate logical conclusion, Sunfism can be completely disconnected from its Islamic roots and perceived as a form of universal mysticism. Haeri, along with many other Muslims including those from within the tariqas, finds this view extremely problematic and labels it as "pseudo-Ṣūfism" (Haeri 1995: 41ff). It is important to acknowledge that the emphasis on such extreme viewpoints by Ṣufis usually originates from members of the nineteenth and twentieth century Sunnī Muslim reform and revivalist movements who often blame Sunfism for the decline of the umma. However, most Șūfis have been equally critical of those who have departed from obedience to the sharía. The vast majority of the taríqas teach that inner development is not possible without the exoteric demands of Islam contained in the final Revelation to humankind from Allāh delivered to and fully manifested in the behaviour of Muhammad, the final prophet of God.

Today Ṣufism remains strong in Egypt, India, Pakistan, Bangladesh, Indonesia, Morocco, sub-Saharan Africa, and is most threatened where secularism and modernity result in a reformed Islam where Șūfism is perceived as a superstitious innovation or relic from a pre-modern past. However, there are signs of a revival throughout the Muslim world, perhaps as a reaction to religious violence as manifested in contemporary jihadism (Geaves 2006; Geaves 2013). Although Süfism organises itself through countless țarīqas owing loyalty to a living or deceased shaykh, the tariqas tend to live in relative harmony with each other, recognising that they are part of a greater whole. Although each group of murids will proclaim the pre-eminence of their founding teacher and his successors, there is a recognition of the affective bonds that lead to these loyalties. Increasingly groups of Șūfis are meeting together, either geographically or in the virtual to promote their version of Islam as normative and to find strength in the battle against secularism and adversaries in the Sunni Muslim world. It is only Wahhābī and Salafi inspired movements with a takfiri mentality who are likely to brand Șüfism as sectarian. However, sharīa-based Șüfi movements are likely to be highly critical of Șūfi movements that are more antinomian.

Wahhābī and Salafi Reactions

As already indicated, within thirty years of the prophet's death dynastic rule had become reality and increasingly accepted as the status quo among Sunnī 
Muslims. In spite of internal conflicts created by dynastic change or aggression on the part of Muslim rulers and warlords towards other territories within the Muslim world, the Sunni world would not face a serious crisis that would threaten the dominance of the theological position contained within "Manifest Success" until the disaster of the Mongol invasion in the thirteenth century (Geaves 2005: 100). Although this event would herald the final destruction of the 'Abbāsid Empire, the Sunnī Muslim world would rise again in the powerful empires of the Ottomans and the Mughals. Religious unity was maintained within the madrasa education system, the chains of transmission (isnād) that provided both legitimacy and authenticity to religious scholarship and to the legal decisions $($ fatw $\bar{a})$ made by the 'ulamä' in localities across the Sunnī Muslim world (Saeed 2006: 123).

The relationship between political administration or governance and Islam was pragmatically reached through a truce, a balance of powers between rulers and religious authorities, with the latter usually compliant to the former, developing Islamic law in a way that facilitated power. Such relations between religion and politics was able to work in majority Muslim populations where governance was maintained by Muslim rulers, with varying degrees of com-

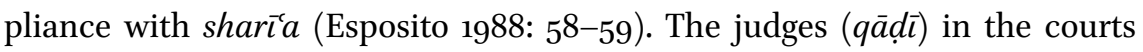
were predominantly trained in the religious domains of the madrasa (Makdisi 1981: 22) However, all of this would be severely strained by the loss of Muslim power to the rising nations of Europe and their respective imperial ambitions in the East and Africa from the eighteenth century onwards (Donohue and Esposito 1982: 5).

The complete or partial loss of state power especially to non-Muslim invaders would be the impulse that resulted in the eventual appearance of Sunni radical or revolutionary reform movements (Tibi 2009: 164-165). In previous eras of crisis, the concept of a renewer of Islam, (mujaddid) follows on from Sunnī ideas of rejuvenation of the umma. As we have seen the doctrine of "Manifest Success" leads to a pattern of religious revival as a response to external crises. In addition, the Muslim worldview of Islam as the final revelation gives an urgent need to protect the 'purity' of God's revealed practices and beliefs. For all Muslims there can be no replacement of their revelation, as they believe happened to Judaism and Christianity (the revelations that were given before the advent of Muhammad and the Qurān) for it is believed that Muhammad was the "seal of the Prophets" and the Qur'ān is the co-eternal Word of God in its entirety. Thus it has come to be a part of traditional Sunnī Muslim belief that Allāh sends a reformer every hundred years to maintain the revelation and destroy any innovatory departure from it. Any movement with a new charismatic leader endowed with personal piety and the energy to impact 
on the world around him can claim that their leader is the mujaddid. A special mujaddid is also believed to appear every thousand years (Geaves 2oogb: 52). The followers of such a personality are likely to become sub-divisions of the Sunnī community but did not, however, divide their world into distinct religious factions or sects (Geaves 2oogb: 52 ).

However, in previous eras of crises, this revival and reform of Sunnì Islam appeared in localised contexts, responding to local crises, but the eighteenth century witnessed Muslim revivals along similar lines across the gamut of the Muslim world. From South-East Asia, through Arabia to Africa, significant Muslim figures created movements to reform Islam. Out of these simultaneous revolutionary responses, perhaps influencing each other through significant meetings at the hajj, the most important has to be the radical attempt to reform the original heartlands of Islam-Arabia—by Muhammad 'Abd al-Wahhāb (1703-1792). The successful cleansing of Arabia of its countless shrines, tombs, and sacred objects associated with popular Șūfism was linked to the Prophet's cleansing of the pagan gods from the Kaba and was achieved by joining the religious zeal of al-Wahhāb with the temporal power of Muhammad ibn Sa'ùd, a local tribal chieftain. The combination was to create the first modern Islamic state, Saudi Arabia, but more significantly a global religious movement that to this day remains influential as it promotes the ideals of its founder throughout the Muslim world as the 'authentic' and 'pure' version of Islam (Geaves 2oogb: 50-51).

Șüfism came to be regarded as the traditional enemy of these neo-orthodox movements long before they perceived the West as a threat and they were prepared to use takfiri tactics on their opponents in the Muslim world. Before the domination of Muslim territory by European powers, any sign of decline in the Muslim community was blamed on inner lapses within the umma and often laid at the door of Șüfism by its critics. With the belief that they were the custodians of the final revelation for humankind from God, the representatives of Islam zealously guarded the community from deviation or innovation. Either of these could lead the community from the straight path and result in a failure to protect the revelation in the original purity of its genesis. Internal political failure or conquest by non-Muslims were both likely to be interpreted as punishment for failing to maintain pristine Islam. Events such as the invasion of the Mongols, which destroyed the 'Abbāsid Empire, or the rise of European domination from the eighteenth century onwards, drove Muslims in upon themselves to examine their own religious belief and practice (Lewis 1968: $5^{2}$ ). As a consequence a number of neo-orthodox movements were born that puritanically tried to purge the Muslim community of religious and cultural accretions said to be the influence of foreign cultures or other religions. Such movements 
were highly critical of Süfism and attempted to present it as a corrupted form of Islam influenced by Buddhists, Neo-Platonists, Hindus, or Christian mystics, depending on the prevalent traditions within a given geographical region. For the neo-orthodox reformers, Șüfism was the cause of Islam's decline and to be eliminated (Geaves 2oogb: 56).

Following on from the armed struggle to purge first Arabia and then the Ottoman Empire by al-Wahhāb, such movements were likely to endorse violence against fellow Muslims. The justification for such jihadist activities was the Khārijite doctrine that Muslims who opposed Islamic reform ('iṣlāh $h$ ) and supported regimes in the Muslim world that compromised with either the sharĩa, the Muhammadan model of rule in Medina, or adopted cultural practices from outside of the Qur'ān and sunna, could be deemed to be käfir or non-Muslim, apostates or hypocrites who had rejected or corrupted the truth of the final revelation. The tactic of takfir, using fatwa to declare rival movements or Muslims who did not declare allegiance to them as outside the world of Islam would radically divide the Muslim world (Esposito 2002: 59-6o). Although sects had existed prior to the advent of these movements in the early modern period, they had not divided the Sunni world. It can be argued that it was the various forms of takfiri movements that gave the impetus to Sunnī sectarianism, dividing and killing other Muslims.

\section{South Asian Sectarianism}

In the nineteenth century, India would experience a proliferation of Islamic movements, some of which would develop into global phenomena. In part these movements would develop as various reactions to the loss of Muslim power in the subcontinent. The thousands of fatwās issued by various 'ulama $\bar{a}^{2}$ would help maintain the boundaries of the various movements that appeared throughout this period. Fatwās were issued to condemn the beliefs and practices of other groups and to give authority to one's own. The fatwās functioned to form group identity and they also allowed for some control over keeping Muslim life within the bounds of the shari $a$ when there was no Muslim state to enforce the law (Geaves 1996: 133-134). The delivery of fatwa would become the main vehicle to call upon the Muslim masses for loyalty to a particular movement and to define the boundaries between movements. For example, in India, the founders of Deoband chose to protect Islam in India through a dual strategy of first providing educational institutions that could supply graduates capable of protecting and maintaining a conservative scripturalist interpretation of Islam in the absence of a Muslim-governed state, and second 
by promoting a deliberate policy of isolation that protected India's Muslims against both Hindu and British cultural influence (Geaves 2015: 193-194). From 1911 the Deobandi movement would maintain a register of its fatwa and in the first century of the college's existence 269,215 fatwäs were issued, most of which focused on belief and ritual (Geaves 1996: 157). In particular, the Deobandī 'ulam $\vec{a}$ c closely examined customs and beliefs associated with Ṣufism to see if they contained bid'a or innovation. In response, the Șüfis were organised into a rival movement by Mawlānā Aḥmad Rizā Khān (1856-1921) which came to be known as the Barelwīs. Ahmmad Rizā Khān and the Barelwī 'ulamā' used their status and legal scholarship consciously to justify a mediatory, custom-laden Islam that was closely linked to the intercession of shrine-based pirs. The aim was to revive and maintain the Islamic status quo as it existed currently. The reformers of Deoband were accused of practising an idealised Islam that was based on texts and historical past and was not properly aligned to the present (Geaves 1996: 95). The two movements still compete with each other globally wherever South Asian Muslims have settled.

In addition to fatwās the Deobandīs took part in preaching and religious debates, and although much of this activity was often directed against Christian missionaries and militant Hindu organisations like the Arya Samaj, another dimension of this debating was between groups within Islam on points of custom and law. These debates helped to establish the boundaries between different Muslim points of view, and assisted the growth of diverse reform movements such as Ahl-i Hadīth and Ahl-i Qurānn, two smaller movements that appeared in the Indian subcontinent and demonstrate how apparently trivial matters regarding textual authority or minor differences in ritual activity could seriously divide Sunnī opinion and form sectarian movements. The Ahl-i Hadìth were more influenced by Arab reformers, particularly those inspired by Wahhābism. They were insistent that learned Muslims should study the Qur'ān and hadith directly rather than through the commentaries of the four schools of law (figh) (Metcalf 2006: $5^{8-59}$ ).

Closely associated with Deoband, was the preaching movement, Tablīghì Jamā'at, established by Muhammad Ilyās in the late 1920s. Ilyās had studied hadìth in Deoband in 1908, and continued as a teacher in Saharanpur until 1910. In 1926 Ilyās visited Mecca and returned with the burning conviction that he should take on the task of teaching Islam to the Muslim masses. To achieve this he went on extensive preaching tours. Unlike the members of Deoband, Ilyās did not feel that it was necessary to be a member of the professional 'ulam $\bar{a}^{3}$ in order to reform Islam. He believed that every Muslim had a responsibility to generate an awareness of Islam to others. He was not interested in reaching out to non-Muslims, but wanted to create a grassroots movement amongst 
Muslims to inspire religious renewal (Anwarul Haq 1972: 86ff). Tablīghī Jamā'at has transcended its South Asian origins and has become a major global movement committed to the revival of Islam.

The Deobandī movement is likely to be labelled as 'Wahhābī' within the milieu of sectarian conflicts between rival Sunnì groups. For example, Muhammad Raza goes on to say that "some Islamic groups under Wahhābī influence stopped their followers from paying respects to the saints in Indo-Pakistani history" (Raza 1993:10). Perhaps more damning is the Deobandī link to the Taliban in Pakistan. William Maley notes that the Taliban's leaders were influenced by Deobandī "fundamentalism" (Maley 20o1: 14). The link to the Taliban arises from the role that the Deobandi dar al-ulums played in the religious education of young Afghan refugees of Pashtun ethnicity on the North-West Frontier during the Russian occupation of Afghanistan. Leading Deobandīs in Pakistan have been connected to the Sipah-i Sahaba Pakistan (SSP), which has been alleged to be involved in terrorist violence, primarily targeted against the minority Shīa community in Pakistan. The movement was also part of the alliance of Jama'at-i Islami (JeI), Jama'at-i 'Ulamä'-i Pakistan (JUP), Jama'at-i 'Ulamā'-i Islam, and Fazlur Rahman's faction of JUI and Jamaat-i Ahl-i Hadìth in forming the Afghan Jehad Council, which claimed that the US action was not a war against Taliban but against Islam, and therefore, it was essential for the Muslims to declare jihād against the US and its allies. Jama'at-i 'Ulamā'-i Pakistan (JUP) and Jama'at-i 'Ulamā'-i Islam are both official bodies of Deobandī 'ulama $\bar{a}^{\prime}$ in Pakistan. From the early 1980s until the early zooos the Deobandī movement in Pakistan was a major recipient of funding from Saudi Arabia until it ceased in favour of the rival Ahl-i Hadith movement, who are today far more likely and accurately to be associated with the Salafi movement.

\section{Mawdūdīan and Quṭbian Reactions}

The Muslim Brotherhood (al-Ikhwān al-Muslimūn) founded in Egypt in 1928 and Jamaat-e-Islami created in India in 1947 are vehicles for the vision of Hasan al-Bannā, later to be succeeded by Sayyid Quṭb (1906-1966) and Mawlānā Mawdūdī (1903-1979). In each case, the primary thrust is political. Both organisations work for an Islamic society based upon the teachings of the Qurān and the hadith. They are essentially regional, with the Brotherhood dominant in the Middle East and Jamaat-Islami in South Asia. As both organisations were founded by non-clerics, their essential approach to interpreting Islam's sources is $i j t i h \bar{a} d$. They are suspicious of taqli $d$, and consider that the 'ulama $\bar{a}^{\prime}$ have been 
partly responsible for Islam's decline (Adams 1983: 100). However, it is their founders' respective analyses of the Islamic state that has made each organisation so influential in the world of Sunnī contestation. I will focus on Mawlānā Mawdūdī as Quțb's ideas are essentially the same, although they would differ on the means to achieve the desired revolution in the Muslim world. Quṭb was more likely to permit violence (jihād) whereas Mawdūdī predominantly favoured "gradualism," that is, education and working within the existing political framework (Khurshid and Ansari 1979: 362).

Mawdūdī consistently argued that the first step in bringing about a genuine Islamic renaissance was to convert the state to Islam. Sharía had to be fully restored, and all laws from other sources repealed. Secular-minded officials had to be replaced, and all the media of education and mass communication had to be utilised towards the creation of an Islamic consciousness in the populaces (Mawdūdī 1986: 14). This is because Islam is more than just a personal faith; it is a complete way of life $(\operatorname{din})$. He stressed that sharía does not recognise any division between religion and other aspects of life, especially between religion and the state. He saw the division between religion and state as a Western invention. Mawdūdī argued that the need for an Islamic state arose from the nature of universal order. God's law governs all creation, but man suffers from the delusion of independence. Nature is under the sway of Islam because it obeys God's natural law, but human beings have the capacity to choose to obey or disobey (Geaves 1996: 183). In order that they may make the correct choice there is revelation. Human behaviour is governed, therefore, by revealed law just as the universe is ruled by natural law. The law which governs human behaviour is fully revealed in the Qur'ann and sunna of the Prophet (Mawdūdī 1985: 18). The key to understanding Mawdūdī's ideas on the necessity of the Islamic state is his interpretation of the kalima or 'word'. He saw the major problem of history not as humankind's denial of the existence of one God but as humankind's unwillingness or refusal to recognise the sovereignty of God (Mawdūdī 1985: 15). Mawdūdī interpreted the kalima as a statement which not only proclaims the uniqueness of God as the Creator or sole object of worship, but also expresses the uniqueness of God as the Master, Sovereign, Lord and law-giver. God alone has the right to command (Mawdūdī 1985b: 72).

It is this revolutionary interpretation of the kalima which provided Mawdūdī with his main critique of the intrusion of Western ideas and philosophy into Muslim society. Secularism, nationalism and Western models for democracy are all based on the idea of the sovereignty of the people. Mawdūdi argued that the acceptance of any other authority as sovereign is a form of shirk, and as such raises that authority to the status of being a partner with Allāh (Adams 1966: 382). The moral evil of the age, which all true Muslims should actively 
oppose, consists of accepting other sovereigns such as "the will of the people" or the laws of worldly rulers and setting them over and above God. True Islamic faith must strive for the creation of an Islamic society as well as individual righteousness. Islam leads individuals to develop a community of faith which promotes social change by creating a society fully obedient to God's law. Mawdūdī called this state "the caliphate based on the prophetic pattern" (Ahmad and Ansari 1979: 20). It is a human caliphate under the sovereignty of God with no power to make new laws, but it will work within the limits prescribed by Allāh by fully implementing sharía. Ideally, the state would be ruled by an amir in consultation with a council (shürā) (Adams 1983: 127). Mawdūdī called this a "theo-democracy" as it was based on the equality of all Muslims under the sovereignty of Allāh (Geaves 1996: 183ff). I have developed Mawdūdī's ideology of an Islamic state as it is so influential among many of the movements that this chapter has explored. Along with Rashīd Riḍa who expressed his vision for the necessity of a reformed Sunnī caliphate in his work Al-Khilafa aw al-Imama al-Uzma (The Caliphate or the Paramount Imamate) written in 1923 (Rida 1923), Mawdūdī and Quṭb have been a major influence on jihadist movements, for example Hizb ut-Tahrir, the Taliban, and Is who struggle to reconstitute a Sunnī caliphate based upon the prophetic model.

\section{$9 \quad$ Conclusion}

Few Muslim commentators are prepared to acknowledge that there are schisms amongst the dominant Sunnīs, despite the fact that for centuries various movements have appeared and ulilised the vehicle of the fatwa to declare their religious opponents as non-Muslim (kufr) (Metcalf 1982:146). Any analysis of these divisions would need to take account of mixed motivation between those who paid nominal allegiance to Islam and those who espoused piety and commitment to the faith. Such an analysis would lead to the post-Weberian sociologists Thomas O'Dea (1964) and Peter Berger (1974: 132), in which there is a constant or recurring tension between the forces which work for stability, even at the risk of distortion and the forces which work for a truer realisation of the initial charismatic moment, whether this is perceived to be the Qurân, the life of the prophets or the salaf. In Șüfism the charismatic moment occurs repeatedly throughout time and geographical locality through the renewal provided by the awliy $\vec{a}^{3}$ (sainthood) (Geaves 2000: 17-18). However, in both Șūi and non-Ṣuffi movements, the impetus to renewal is located in the concept of the mujahid, the reformer of the century, who is sent to preserve the Sunnī tradition from decay or innovation (Geaves 2oogb: $5^{2}$ ). 
Fundamental to this contestation of Sunnì authenticity, is the hadith that proclaims that the Prophet's community would divide into seventy-two sects with only one maintaining the true Islam. Obviously each movement feels itself to be that one and its competitors to be the heretical remainder. Yet, the saying itself provides the stimulus for sectarian movements to appear as each new reformer and his followers see themselves as the one that maintains true Islam. I have argued that these analyses of division tend to fall into two categories: those that seek political causes and those that explore theological or religious differences. Yet it becomes clear that in most cases, Sunnī contestations concern governance. Thus historically, any attempt to discover the causes of schism in the early community of Muslims would need to take account of the expansion of the Arab empire and the absorption of a variety of social groups into the religio-political entity (umma). The issue here is not only political and economic, but the fear of a dilution or a distortion of the original Arab revelation. It has to be remembered that the religion of Islam was to turn into a body politic in a very short number of years. Tensions between the religious worldview of the pious and their rulers, between those that offered their loyalty to the revelation and those who gave it primarily to the state were endemic. The link between religion and state was so powerful that those who broke away from the religion or deviated from orthodoxy were likely to be seen as traitors, punishable by legal codes.

The success of the Sunnì majority was to come at the price of religious life, and caused dreadful soul searching when territory was lost to non-Muslim forces. Khuri looks at Sunnī sectarian formation and assesses it in the context of state structures, centralised authority, the resort to coercive measures and the tendency to standardise. He argues that it is a "fabric fitted together by the logic of power and conquest" (Khuri 199o: 19). The logic of Khuri's analysis leads to a conclusion that sectarianism within the Muslim world can be explained as instruments of moral control operating outside the heartlands of the Arab empire, either outside the arena of state authority or consciously resisting it for either political or religious reasons. In Khuri's argument sects and state stand in opposition to one another (Khuri 1990:17-18). Such an analysis would help to explain the 'invented charisma' of Imams, Șufis, and one hundred year renewers of the faith (mujaddid). Their miraculous powers, heroic personalities and hagiographies functioned to provide a different authority to that of the bureaucratic state; a resistance to the state monopoly of religion, all legitimised by an immediate access to the divine providing the means to negate all-powerful human authorities by the display of supernatural powers that even overturned the laws of nature (Geaves 2009a: 59). To such figures, invented or otherwise, flocked the dispossessed, the powerless, the seekers of 
justice, ethnic and tribal minorities, the searchers for God or merely those that were too far from the centres of power to feel its influence (Geaves 2ooga: 59).

The contemporary era has added the complication of the loss of Muslim power and the result has brought out far more sectarianism within the Sunnī world than in earlier centuries when Muslim civilisation remained dominant. As the fundamentals of the faith remain solidly the same, even in warring groups, Metcalf's contestation for religious authenticity in which she argues that 'contestation' indicates the degree to which Muslims have engaged in recent centuries in renewing and rethinking the historic traditions of their religion (Metcalf 2006: 3) or Asad's (1986) imagined community may provide more scope for analysis of the current situation than sectarianism.

\section{References}

AbdAllāh, S.S. 2006. "Ibn Taymiyyah on the Hadīth of the 73 Sects." Jurnal Akidah \& Pemikiran Islam. 7:1, 35-62.

Adams, C. 1966. "The Ideology of Maulana Mawdūdī." In D. Smith ed., South Asian Politics and Religion. Princeton: Princeton University Press, 389-392.

Adams, C. 1983. "Mawdūdī and the Islamic State." In J. Esposito ed., Voices of Resurgent Islam. New York: Oxford University Press, 99-133.

Afsaruddin, A. 2015. Contemporary Issues in Islam. Edinburgh: Edinburgh University Press.

Ahmad, K. and Z. Ansari. 1979. Islamic Perspectives. Leicester: The Islamic Foundation. Al-Raziq, A. 1966 [1925]. Al-Islam wa Usul al-Hukm:Bahth fial-Khilafah wa al-Hukumah fi al-Islam. Second Edition. Beirut: Dar Maktabah bi al-Hayah.

Anderson, B. 1991. Imagined communities: Reflections on the Origin and Spread of Nationalism. London: Verso.

Asad, T. 1986. The Idea of the Anthropology of Islam. Washington: Georgetown University Press.

Asad, T. 2009. "The Idea of the Anthropology of Islam." Qui Parle. 17:2, 1-30.

Berger, P. 1974. "Some Second Thoughts on Substantive Versus Functional Definitions of Religion." Journal for the Scientific Study of Religion. 13:2, 125-133.

Dawud, S. (N.d.) Model Behaviour of the Prophet (Kitab al-Sunnah). At https://sunnah .com/abudawud/42. Accessed 27/10/2018.

Donner, F. 2010. Muhammad and the Believers: At the Origins of Islam. Cambridge, MA and London: Belknap Press of Harvard University Press.

Donohue, J. and J. Esposito. 1982. Islam in Transition. Oxford: Oxford University Press.

Dressler, M., R. Geaves, and G. Klinkhammer. 20og. "Introduction." In M. Dressler, R. Geaves, G. Klinkhammer eds, Sufis in Western Society. London: Routledge, 1-12. 
El-Fadl, K. 2007. The Great Theft: Wrestling Islam from the Extremists. New York: Harper Collins.

Ernst, C. 1997. The Shambhala Guide to Sufism. Boston: Shambhala.

Esposito, J. 1988. Islam: The Straight Path. Oxford: Oxford University Press.

Fakhry, M. 1983. A History of Islamic Philosophy. 2nd Ed. New York: Columbia University Press.

Fakhry, M. 2002. Unholy War: Terror in the Name of Islam. Oxford: Oxford University Press.

Foy, W. (ed). 1978. Man's Religious Quest. Milton Keynes: The Open University.

Geaves, R. 1996. "Sectarian Influences within Islam in Britain with reference to the concepts of 'umma' and 'community'. Doctoral dissertation, University of Leeds. At http://arts.leeds.ac.uk/crp/files/2015/og/geaves1996.pdf. Accessed 27/10/2018.

Geaves, R. 200o. Sufis of Britain. Cardiff: Cardiff Academic Press.

Geaves, R. 2005. Aspects of Islam. London and Washington: Darton, Longman \& Todd/ Georgetown University Press.

Geaves, R. 2006. "Learning the lessons from the neo-revivalist and Wahhābī movements: the Counterattack of new Sufi movements in the UK." In J. Malik and J. Hinnells eds, Sufism in the West. London: Routledge, 142-159.

Geaves, R. 20oga. "A Case of Cultural Binary Fission or Transglobal Sufism? The Transmigration of Sufism to Britain" in M. Dressler, R. Geaves, G. Klinkhammer eds, Global Networking and Locality: Sufis in Western Society. London: Routledge, 77-97.

Geaves, R. 2009b. "Charismatic Authority in Islam: An Analysis of the Cause of Schisms in the Umma." In J.R. Lewis and S.M. Lewis eds, Sacred Schisms: How Religions Divide. Cambridge University Press, 37-6o.

Geaves, R. 2010. Islam in Victorian Britain: The Life and Times of Abdullah Quilliam. Leicester: Kube Press.

Geaves, R. 2013. “'That which we have forgotten': The Emergence of 'Traditional Islam' as a New Movement in Global Muslim Religious Contestation." Journal for the Academic Study of Religion. 26:1, 29-5o.

Geaves, R. 2015. “The Contested Milieu of Deoband: 'Salafis' or 'Sufis'?” In L. Ridgeon ed., Sufis and Salafis in the Contemporary Age. London: Bloomsbury, 191-206.

Gilham, J. 2014. Loyal Enemies: British Converts to Islam 1850-1950. London: Hurst \& Co. Haeri, S. 1995. The Elements of Sufism. Shaftesbury: Element Books.

Hamid, S. 2016. Sufis, Salafis and Islamists. London: IB Tauris.

Haq, M. 1972. The Faith Movement of Mawlana Muhammad Ilyas. London: George Allen \& Unwin.

Khuri, F. 199o. Imams and Emir: State, Religion and Sects in Islam. London: Saqi Books.

Kniss, F. and P. Numrich. 2007. Sacred Assemblies and Civic Engagement. Rutgers University Press. 
Knysh, A. 2017. Sufism: A New History of Islamic Mysticism. Princeton and Oxford: Princeton University Press.

Lapidus, I. 1988. A History of Islamic Societies. Cambridge: Cambridge University Press. Lewis, B. 1968. "The Mongols, the Turks, and the Muslim Polity." Transactions of the Royal Historical Society. 18, 49-68.

Makdisi, G. 1981. The Rise of Colleges. Edinburgh: Edinburgh University Press.

Maley, W. 2001. Fundamentalism Reborn? Afghanistan and the Taliban. London: Hurst. Mawdūdī, S. 1985a. Towards Understanding Islam. Leicester: The Islamic Foundation.

Mawdūdī, S. 1985b. Let us be Muslims. Leicester: The Islamic Foundation.

Mawdūdī, S. 1986. The Islamic Way of Life. Leicester: The Islamic Foundation.

McGuire, M. 2002. Religion: The Social Context. Waveland Press.

Metcalf, B. 2002. Islamic Revival in British India: Deoband 1860-1900. Princeton: Princeton University Press.

Metcalf, B. 2006. "Two Fatwā on Hajj in British India." In B. Metcalf, ed., Islamic Contestations: Essays on Muslims in India and Pakistan. Second Edition. New Delhi: Oxford India Paperbacks.

Moten, A.R. 1996. Political Science: An Islamic Perspective. London: Palgrave Macmillan.

Nicholson, R. 1989 [1914]. The Mystics of Islam. Fourth Edition. Harmondsworth: Penguin Arkana.

O’Dea, T.F. 1964. "Sociological Dilemmas: Five Paradoxes of Institutionalisation." In E. Tiryakian, E. (ed.) Sociological Theory, Values, and Socio-Cultural Change. New York: The Free Press of Glencoe, 71-89.

Raza, M. 1993. Islam in Britain: Past, Present and Future. Leicester: Volcano Press.

Rida, R. 1923. Al-Khilafa aw al-Imama al-'Uzma (The Caliphate or the Paramount Imamate). Cairo: Matbaat al-Manar.

Saeed, A. 2006. Islamic Thought: An Introduction. London: Routledge.

Stark, R. and W. Bainbridge. 1979. "Of Churches, Sects, and Cults: Preliminary Concepts for a Theory of Religious Movements." Journal for the Scientific Study of Religion. 18:2, 117-33.

Tibi, B. 20o9. Islam's Predicament with Modernity. London: Routledge.

Timani, H.S. 2008. Modern Intellectual Readings of the Khārijites. New York and Bern: Peter Lang.

Troeltsch, E. 1931. The Social Teachings of the Christian Churches. Vol. 1. New York: Macmillan.

Van der Veer, P. 1992. "Playing or Praying: A Sufi Saint's Day in Surat." The Journal of Asian Studies. 51:3, 545-564.

Wallis, R. 1975. "Scientology: Therapeutic Cult to Religious Sect." Sociology. 9:1, 89-10o.

Weber, M. 1973. “On Church, Sect, and Mysticism." Sociological Analysis, 34:2, 140-149. 